\title{
A Study On Customer Satisfaction Of Commercial Banks: Case Study On State Bank Of India
}

\author{
Amruth Raj Nippatlapalli \\ Business Management,V.R.College, Vikrama Simhapuri University,India
}

\begin{abstract}
Customer satisfaction, a term frequently used in marketing, is a measure of how products and services supplied by a company meet or surpass customer expectation. Customer satisfaction is defined as "the number of customers, or percentage of total customers, whose reported experience with a firm, its products, or its services (ratings) exceeds specified satisfaction goals. "Banking in India originated in the last decades of the 18th century. The first banks were The General Bank of India, NOW which started in 1786, and Bank of Hindustan, which started in 1790; both are now defunct. The oldest bank in existence in India is the State Bank of India, which originated in the Bank of Calcutta in June 1806, which almost immediately became the Bank of Bengal. This was one of the three presidency banks, the other two being the Bank of Bombay and the Bank of Madras, all three of which were established under charters from the British East India Company. For many years the Presidency banks acted as quasi-central banks, as did their successors. The three banks merged in 1921 to form the Imperial Bank of India.
\end{abstract}

Keywords: Bankinghistory in INDIA, Conclusion, Customers satisfaction, List of Commercial Banks, Research Methodology,

\section{Introduction}

"Customer satisfaction is measured at the individual level, but it is almost always reported at an aggregate level. It can be, and often is, measured along various dimensions. A hotel, for example, might ask customers to rate their experience with its front desk and check-in service, with the room, with the amenities in the room, with the restaurants, and so on.

Customer satisfaction, a term frequently used in marketing, is a measure of how products and services supplied by a company meet or surpass customer expectation. Customer satisfaction is defined as "the number of customers, or percentage of total customers, whose reported experience with a firm, its products, or its services (ratings) exceeds specified satisfaction goals." In a survey of nearly 200 senior marketing managers, 71 percent responded that they found a customer satisfaction metric very useful in managing and monitoring their businesses.

"Customer satisfaction provides a leading indicator of consumer purchase intentions and loyalty." "Customer satisfaction data are among the most frequently collected indicators of market perceptions.

Customer service is the provision of service to customers before, during and after a purchase. According to Turban et al. (2002), "Customer service is a series of activities designed to enhance the level of customer satisfaction - that is, the feeling that a product or service has met the customer expectation."

Customer satisfaction is an ambiguous and abstract concept and the actual manifestation of the state of satisfaction will vary from person to person and product/service to product/service. The state of satisfaction depends on a number of both psychological and physical variables which correlate with satisfaction behaviors such as return and recommend rate. The level of satisfaction can also vary depending on other options the customer may have and other products against which the customer can compare the organization's services

\section{Industry Profile:}

Banking in India:

Banking in India originated in the last decades of the 18th century. The first banks were The General Bank of India, NOW which started in 1786, and Bank of Hindustan, which started in 1790; both are now defunct. The oldest bank in existence in India is the State Bank of India, which originated in the Bank of Calcutta in June 1806, which almost immediately became the Bank of Bengal. This was one of the three presidency banks, the other two being the Bank of Bombay and the Bank of Madras, all three of which were established under charters from the British East India Company. For many years the Presidency banks acted as quasi-central banks, as did their successors. The three banks merged in 1921 to form the Imperial Bank of India , which, upon India's independence, became the State Bank of India in 1955. 
History:

Indian merchants in Calcutta established the Union Bank in 1839, but it failed in 1848 as a consequence of the economic crisis of 1848-49. The Allahabad Bank, established in 1865 and still functioning today, is the oldest Joint Stock bank in India.(Joint Stock Bank: A company that issues stock and requires shareholders to be held liable for the company's debt) It was not the first though. That honor belongs to the Bank of Upper India, which was established in 1863, and which survived until 1913, when it failed, with some of its assets and liabilities being transferred to the Alliance Bank of Simla.

When the American Civil War stopped the supply of cotton to Lancashire from the Confederate States, promoters opened banks to finance trading in Indian cotton. With large exposure to speculative ventures, most of the banks opened in India during that period fey and lost interest in keeping deposits with banks. Subsequently, banking in India remained the exclusive domain of Europeans for next several decades until the beginning of the 20th century.

Foreign banks too started to arrive, particularly in Calcutta, in the 1860s. The Comptoire d'Escompte de Paris opened a branch in Calcutta in 1860, and another in Bombay in 1862; branches in Madras and Pondicherry, then a French colony, followed. HSBC established itself in Bengal in 1869. Calcutta was the most active trading port in India, mainly due to the trade of the British Empire, and so became a banking center.

The first entirely Indian joint stock bank was the Oudh Commercial Bank, established in 1881 in Faizabad. It failed in 1958. The next was the Punjab National Bank, established in Lahore in 1895, which has survived to the present and is now one of the largest banks in India.

Around the turn of the 20th Century, the Indian economy was passing through a relative period of stability. Around five decades had elapsed since the Indian Mutiny, and the social, industrial and other infrastructure had improved. Indians had established small banks, most of which served particular ethnic and religious communities.

The presidency banks dominated banking in India but there were also some exchange banks and a number of Indian joint stock banks. All these banks operated in different segments of the economy. The exchange banks, mostly owned by Europeans, concentrated on financing foreign trade. Indian joint stock banks were generally under capitalized and lacked the experience and maturity to compete with the presidency and exchange banks. This segmentation let Lord Curzon to observe, "In respect of banking it seems we are behind the times. We are like some old fashioned sailing ship, divided by solid wooden bulkheads into separate and cumbersome compartments."

The period between 1906 and 1911, saw the establishment of banks inspired by the Swadeshi movement. The Swadeshi movement inspired local businessmen and political figures to found banks of and for the Indian community. A number of banks established then have survived to the present such as Bank of India, Corporation Bank, Indian Bank, Bank of Baroda, Canara Bank and Central Bank of India.

The fervour of Swadeshi movement lead to establishing of many private banks in Dakshina Kannada and Udupi district which were unified earlier and known by the name South Canara ( South Kanara ) district. Four nationalised banks started in this district and also a leading private sector bank. Hence undivided Dakshina Kannada district is known as "Cradle of Indian Banking".

During the First World War (1914-1918) through the end of the Second World War (1939-1945), and two years thereafter until the independence of India were challenging for Indian banking. The years of the First World War were turbulent, and it took its toll with banks simply collapsing despite the Indian economy gaining indirect boost due to war-related economic activities.

At least 94 banks in India failed between 1913 and 1918 as indicated in the following table:

\begin{tabular}{|r|r|r|r|}
\hline \multirow{2}{*}{ Years } & \multicolumn{2}{|c|}{ Number of banks } & \multicolumn{2}{c|}{ Authorised capital } & \multicolumn{2}{c|}{ Paid-up Capital } \\
\cline { 2 - 5 } & \multicolumn{2}{|c|}{ that failed } & \multicolumn{2}{c|}{ (Rs. Lakhs) } & (Rs. Lakhs) \\
\hline 1913 & 12 & 274 & 109 \\
\hline 1914 & 42 & 710 & 5 \\
\hline 1915 & 11 & 56 & 4 \\
\hline 1916 & 13 & 231 & 25 \\
\hline 1917 & 9 & 76 & 1 \\
\hline 1918 & 7 & 209 & \\
\hline
\end{tabular}

\section{Post Independence Era:}

The partition of India in 1947 adversely impacted the economies of Punjab and West Bengal, paralyzing banking activities for months. India's independence marked the end of a regime of the Laissez-faire for the Indian banking. The Government of India initiated measures to play an active role in the economic life of the nation, and the Industrial Policy Resolution adopted by the government in 1948 envisaged a mixed economy. 
This resulted into greater involvement of the state in different segments of the economy including banking and finance. The major steps to regulate banking included:

- The Reserve Bank of India, India's central banking authority, was established in April 1934, but was nationalized on January 1, 1949 under the terms of the Reserve Bank of India (Transfer to Public Ownership) Act, 1948 (RBI, 2005b).

- In 1949, the Banking Regulation Act was enacted which empowered the Reserve Bank of India (RBI) "to regulate, control, and inspect the banks in India".

- The Banking Regulation Act also provided that no new bank or branch of an existing bank could be opened without a license from the RBI, and no two banks could have common directors.

\section{Nationalization:}

Despite the provisions, control and regulations of Reserve Bank of India, banks in India except the State Bank of India or SBI, continued to be owned and operated by private persons. By the 1960s, the Indian banking industry had become an important tool to facilitate the development of the Indian economy. At the same time, it had emerged as a large employer, and a debate had ensued about the nationalization of the banking industry. Indira Gandhi, then Prime Minister of India, expressed the intention of the Government of India in the annual conference of the All India Congress Meeting in a paper entitled "Stray thoughts on Bank Nationalisation. "The meeting received the paper with enthusiasm.

Thereafter, her move was swift and sudden. The Government of India issued an ordinance ('Banking Companies (Acquisition and Transfer of Undertakings) Ordinance, 1969')) and nationalised the 14 largest commercial banks with effect from the midnight of July 19, 1969. These banks contained 85 percent of bank deposits in the country. Jayaprakash Narayan, a national leader of India, described the step as a "masterstroke of political sagacity." Within two weeks of the issue of the ordinance, the Parliament passed the Banking Companies (Acquisition and Transfer of Undertaking) Bill, and it received the presidential approval on 9 August 1969.

A second dose of nationalization of 6 more commercial banks followed in 1980. The stated reason for the nationalization was to give the government more control of credit delivery. With the second dose of nationalization, the Government of India controlled around $91 \%$ of the banking business of India. Later on, in the year 1993, the government merged New Bank of India with Punjab National Bank. It was the only merger between nationalized banks and resulted in the reduction of the number of nationalised banks from 20 to 19 . After this, until the 1990s, the nationalised banks grew at a pace of around $4 \%$, closer to the average growth rate of the Indian economy.

\section{Liberalization:}

In the early 1990s, the then Narasimha Rao government embarked on a policy of liberalization, licensing a small number of private banks. These came to be known as New Generation tech-savvy banks, and included Global Trust Bank (the first of such new generation banks to be set up), which later amalgamated with Oriental Bank of Commerce, Axis Bank(earlier as UTI Bank), ICICI Bank and HDFC Bank. This move, along with the rapid growth in the economy of India, revitalized the banking sector in India, which has seen rapid growth with strong contribution from all the three sectors of banks, namely, government banks, private banks and foreign banks.

The next stage for the Indian banking has been set up with the proposed relaxation in the norms for Foreign Direct Investment, where all Foreign Investors in banks may be given voting rights which could exceed the present cap of $10 \%$, at present it has gone up to $74 \%$ with some restrictions.

The new policy shook the Banking sector in India completely. Bankers, till this time, were used to the 4-6-4 method (Borrow at 4\%; Lend at 6\%; Go home at 4 ) of functioning. The new wave ushered in a modern outlook and tech-savvy methods of working for traditional banks.All this led to the retail boom in India. People not just demanded more from their banks but also received more.

Currently (2010), banking in India is generally fairly mature in terms of supply, product range and reach-even though reach in rural India still remains a challenge for the private sector and foreign banks. In terms of quality of assets and capital adequacy, Indian banks are considered to have clean, strong and transparent balance sheets relative to other banks in comparable economies in its region. The Reserve Bank of India is an autonomous body, with minimal pressure from the government. The stated policy of the Bank on the Indian Rupee is to manage volatility but without any fixed exchange rate-and this has mostly been true.

With the growth in the Indian economy expected to be strong for quite some time-especially in its services sector-the demand for banking services, especially retail banking, mortgages and investment services are expected to be strong. One may also expect M\&As, takeovers, and asset sales. 
In March 2006, the Reserve Bank of India allowed Warburg Pincus to increase its stake in Kotak Mahindra Bank (a private sector bank) to $10 \%$. This is the first time an investor has been allowed to hold more than $5 \%$ in a private sector bank since the RBI announced norms in 2005 that any stake exceeding $5 \%$ in the private sector banks would need to be vetted by them.

In recent years critics have charged that the non-government owned banks are too aggressive in their loan recovery efforts in connection with housing, vehicle and personal loans. There are press reports that the banks' loan recovery efforts have driven defaulting borrowers to suicide.

\section{Adoption of Technology in Banking System:}

The IT revolution had a great impact in the Indian banking system. The use of computers had led to introduction of online banking in India. The use of the modern innovation and computerisation of the banking sector of India has increased many fold after the economic liberalisation of 1991 as the country's banking sector has been exposed to the world's market. The Indian banks were finding it difficult to compete with the international banks in terms of the customer service without the use of the information technology and computers

The RBI in 1984 formed Committee on Mechanisation in the Banking Industry (1984) whose chairman was Dr C Rangarajan, Deputy Governor, Reserve Bank of India. The major recommendations of this committee was introducing MICR Technology in all the banks in the metropolis in India.This provided use of standardized cheque forms and encoders.

In 1988, the RBI set up Committee on Computerisation in Banks (1988) headed by Dr. C.R. Rangarajan which emphasized that the settlement operation must be computerized in the clearing houses of RBI in Bhubaneshwar, Guwahati, Jaipur, Patna and Thiruvananthapuram.It further stated that there should be National Clearing of inter-city cheques at Kolkata,Mumbai,Delhi,Chennai and MICR should be made Operational.It also focused on computerisation of branches and increasing connectivity among branches through computers.It also suggested modalities for implementing on-line banking.The committee submitted its reports in 1989 and computerisation began form 1993 with settlement between IBA and bank employees'association. In 1994, Committee on Technology Issues relating to Payments System, Cheque Clearing and Securities Settlement in the Banking Industry (1994) ${ }^{[10] \mathrm{z}}$ was set up with chairman Shri WS Saraf, Executive Director, Reserve Bank of India. It emphasized on Electronic Funds Transfer (EFT) system, with the BANKNET communications network as its carrier. It also said that MICR clearing should be set up in all branches of all banks with more than 100 branches.

Committee for proposing Legislation On Electronic Funds Transfer and other Electronic Payments (1995) emphasized on EFT system. Electronic banking refers to DOING BANKING by using technologies like computers, internet and networking,MICR,EFT so as to increase efficiency, quick service,productivity and transparency in the transaction.

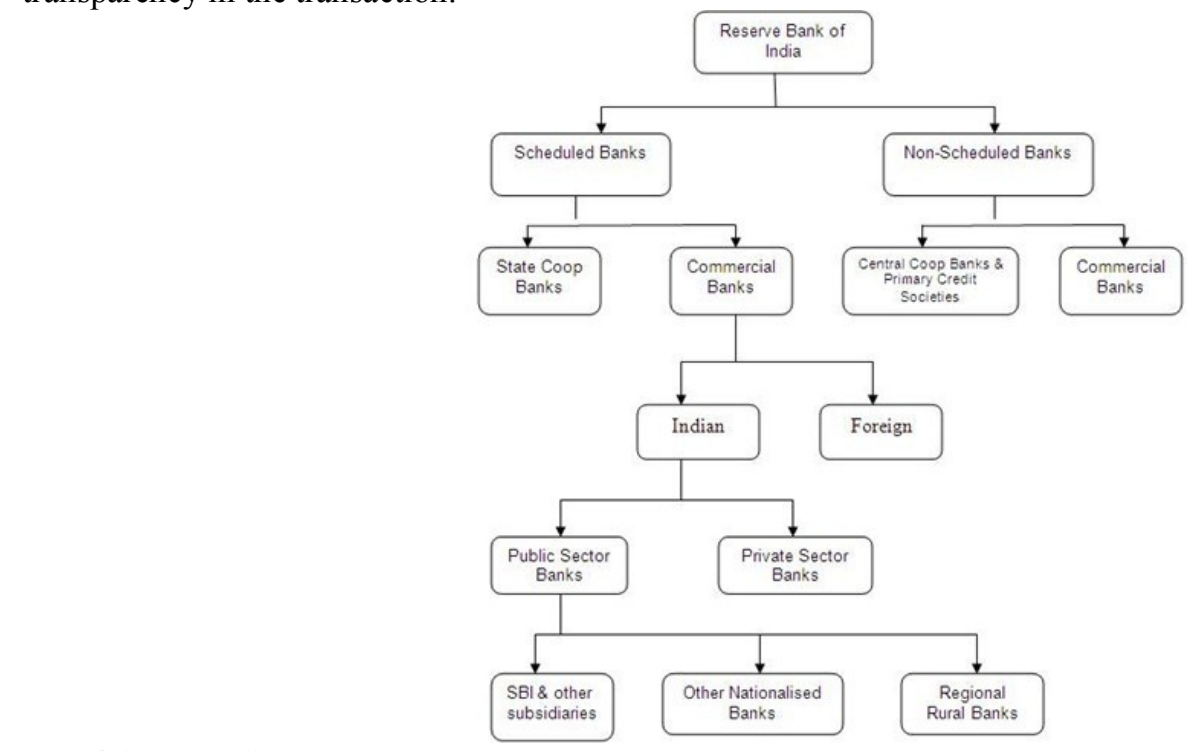

List Of Public Sector Banks in INDIA:

Central Bank:

1. Reserve Bank of India (RBI)

Public Sector Banks (Nationalised banks):

1. State Bank of India (SBI)

2. State Bank of Bikaner \& Jaipur 
3. State Bank of Hyderabad

4. State Bank of Indore

5. State Bank of Mysore

6. State Bank of Patiala

7. State Bank of Saurashtra

8. State Bank of Travancore

9. Bank of India

10. Canara Bank

11. Central Bank of India

12. Corporation bank

13. Indian Bank

14. Indian overseas bank

15. Syndicate Bank

16. UCO Bank

17. Allahabad Bank

18. Andhra Bank

19. Bank of Baroda

20. Bank of Maharashtra

21. Dena Bank

22. Oriental Bank of Commerce

23. Punjab \& Sind Bank

24. Union Bank of India

25. United Bank of India

26. Vijaya Bank

27. IDBI Bank

Company Profile

\section{State Bank Of India History:}

The origin of the State Bank of India goes back to the first decade of the nineteenth century with the establishment of the Bank of Calcutta in Calcutta on 2 June 1806. Three years later the bank received its charter and was re-designed as the Bank of Bengal (2 January 1809). A unique institution, it was the first joint-stock bank of British India sponsored by the Government of Bengal. The Bank of Bombay (15 April 1840) and the Bank of Madras (1 July 1843) followed the Bank of Bengal. These three banks remained at the apex of modern banking in India till their amalgamation as the Imperial Bank of India on 27 January 1921.

Primarily Anglo-Indian creations, the three presidency banks came into existence either as a result of the compulsions of imperial finance or by the felt needs of local European commerce and were not imposed from outside in an arbitrary manner to modernise India's economy. Their evolution was, however, shaped by ideas culled from similar developments in Europe and England, and was influenced by changes occurring in the structure of both the local trading environment and those in the relations of the Indian economy to the economy of Europe and the global economic framework.

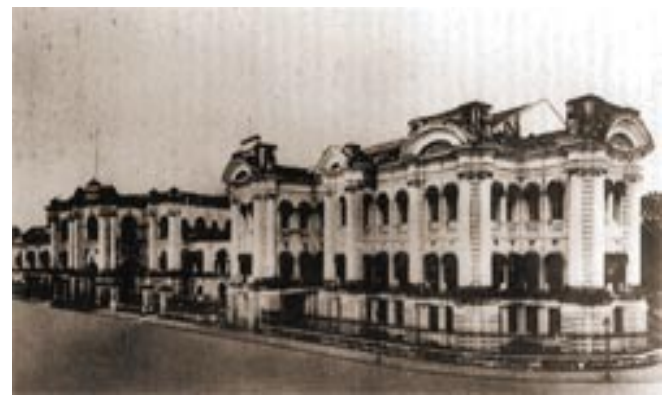

Bank of Bangal Head Office

\section{Establishment}

The establishment of the Bank of Bengal marked the advent of limited liability, joint-stock banking in India. So was the associated innovation in banking, viz. the decision to allow the Bank of Bengal to issue notes, which would be accepted for payment of public revenues within a restricted geographical area. This right of note issue was very valuable not only for the Bank of Bengal but also its two siblings, the Banks of Bombay and Madras. It meant an accretion to the capital of the banks, a capital on which the proprietors did not have to pay any interest. The concept of deposit banking was also an innovation because the practice of accepting money for safekeeping (and in some cases, even investment on behalf of the clients) by the indigenous bankers had not spread as a 
general habit in most parts of India. But, for a long time, and especially upto the time that the three presidency banks had a right of note issue, bank notes and government balances made up the bulk of the investible resources of the banks.

The three banks were governed by royal charters, which were revised from time to time. Each charter provided for a share capital, four-fifth of which were privately subscribed and the rest owned by the provincial government. The members of the board of directors, which managed the affairs of each bank, were mostly proprietary directors representing the large European managing agency houses in India. The rest were government nominees, invariably civil servants, one of whom was elected as the president of the board.

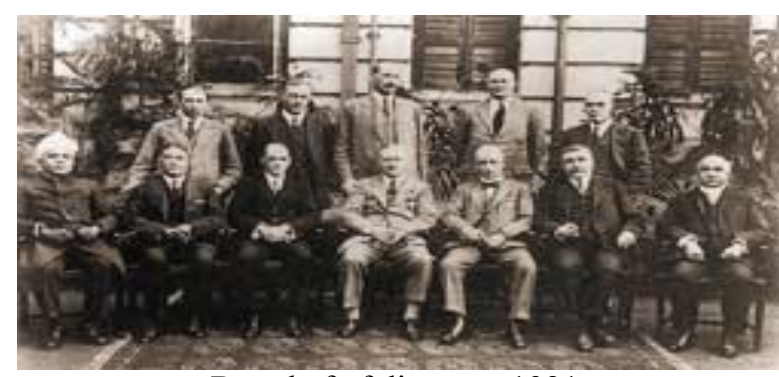

Board of of directors 1921

\section{Business}

The business of the banks was initially confined to discounting of bills of exchange or other negotiable private securities, keeping cash accounts and receiving deposits and issuing and circulating cash notes. Loans were restricted to Rs.one lakh and the period of accommodation confined to three months only. The security for such loans was public securities, commonly called Company's Paper, bullion, treasure, plate, jewels, or goods 'not of a perishable nature' and no interest could be charged beyond a rate of twelve per cent. Loans against goods like opium, indigo, salt woollens, cotton, cotton piece goods, mule twist and silk goods were also granted but such finance by way of cash credits gained momentum only from the third decade of the nineteenth century. All commodities, including tea, sugar and jute, which began to be financed later, were either pledged or hypothecated to the bank. Demand promissory notes were signed by the borrower in favour of the guarantor, which was in turn endorsed to the bank. Lending against shares of the banks or on the mortgage of houses, land or other real property was, however, forbidden.

Indians were the principal borrowers against deposit of Company's paper, while the business of discounts on private as well as salary bills was almost the exclusive monopoly of individuals Europeans and their partnership firms. But the main function of the three banks, as far as the government was concerned, was to help the latter raise loans from time to time and also provide a degree of stability to the prices of government securities.

\section{Major change inthe conditions:}

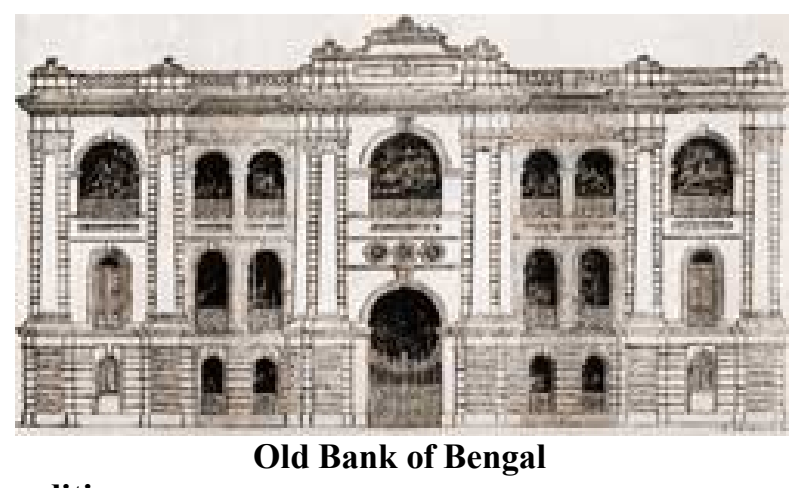

A major change in the conditions of operation of the Banks of Bengal, Bombay and Madras occurred after 1860. With the passing of the Paper Currency Act of 1861, the right of note issue of the presidency banks was abolished and the Government of India assumed from 1 March 1862 the sole power of issuing paper currency within British India. The task of management and circulation of the new currency notes was conferred on the presidency banks and the Government undertook to transfer the Treasury balances to the banks at places where the banks would open branches. None of the three banks had till then any branches (except the sole attempt and that too a short-lived one by the Bank of Bengal at Mirzapore in 1839) although the charters had given them such authority. But as soon as the three presidency bands were assured of the free use of government Treasury balances at places where they would open branches, they embarked on branch expansion at a rapid pace. By 1876, the branches, agencies and sub agencies of the three presidency banks covered most of the major 
parts and many of the inland trade centres in India. While the Bank of Bengal had eighteen branches including its head office, seasonal branches and sub agencies, the Banks of Bombay and Madras had fifteen each.

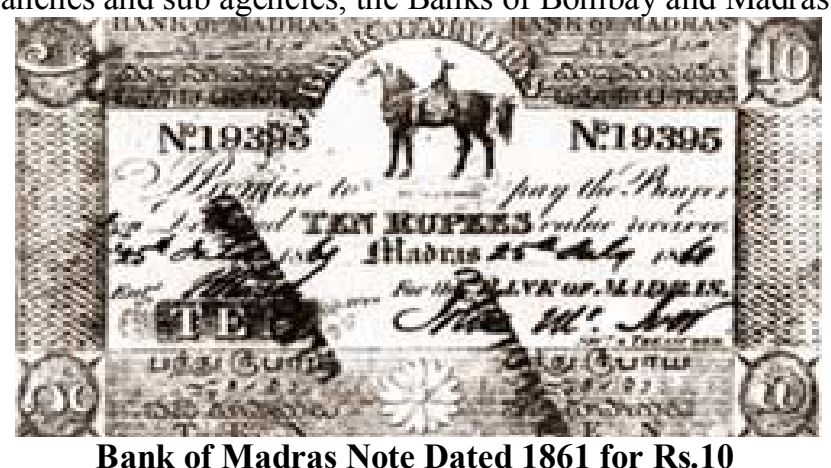

\section{Presidency Banks Act:}

The presidency Banks Act, which came into operation on 1 May 1876, brought the three presidency banks under a common statute with similar restrictions on business. The proprietary connection of the Government was, however, terminated, though the banks continued to hold charge of the public debt offices in the three presidency towns, and the custody of a part of the government balances. The Act also stipulated the creation of Reserve Treasuries at Calcutta, Bombay and Madras into which sums above the specified minimum balances promised to the presidency banks at only their head offices were to be lodged. The Government could lend to the presidency banks from such Reserve Treasuries but the latter could look upon them more as a favour than as a right.

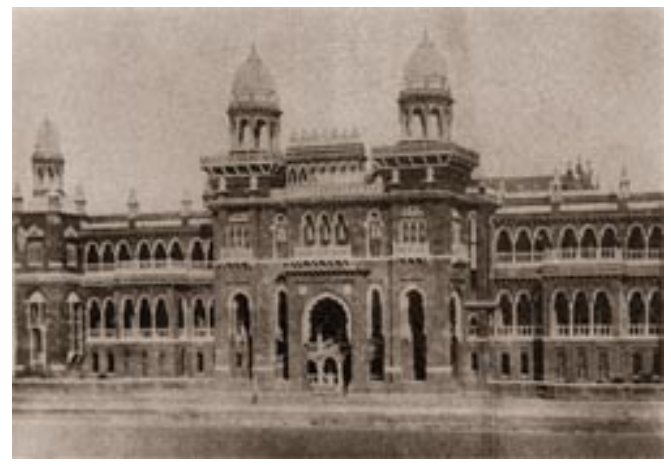

Bank of Madras

The decision of the Government to keep the surplus balances in Reserve Treasuries outside the normal control of the presidency banks and the connected decision not to guarantee minimum government balances at new places where branches were to be opened effectively checked the growth of new branches after 1876 . The pace of expansion witnessed in the previous decade fell sharply although, in the case of the Bank of Madras, it continued on a modest scale as the profits of that bank were mainly derived from trade dispersed among a number of port towns and inland centres of the presidency.

India witnessed rapid commercialisation in the last quarter of the nineteenth century as its railway network expanded to cover all the major regions of the country. New irrigation networks in Madras, Punjab and Sind accelerated the process of conversion of subsistence crops into cash crops, a portion of which found its way into the foreign markets. Tea and coffee plantations transformed large areas of the eastern Terais, the hills of Assam and the Nilgiris into regions of estate agriculture par excellence. All these resulted in the expansion of India's international trade more than six-fold. The three presidency banks were both beneficiaries and promoters of this commercialisation process as they became involved in the financing of practically every trading, manufacturing and mining activity in the sub-continent. While the Banks of Bengal and Bombay were engaged in the financing of large modern manufacturing industries, the Bank of Madras went into the financing of large modern manufacturing industries, the Bank of Madras went into the financing of small-scale industries in a way which had no parallel elsewhere. But the three banks were rigorously excluded from any business involving foreign exchange. Not only was such business considered risky for these banks, which held government deposits, it was also feared that these banks enjoying government patronage would offer unfair competition to the exchange banks which had by then arrived in India. This exclusion continued till the creation of the Reserve Bank of India in 1935 . 


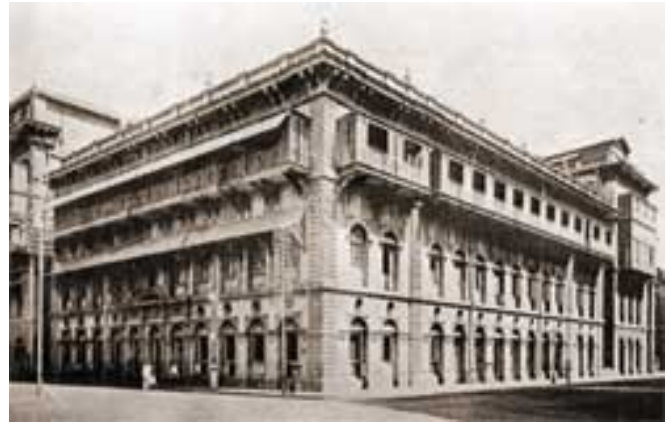

Presidency Banks of Bengal:

Bank of Bombay

The presidency Banks of Bengal, Bombay and Madras with their 70 branches were merged in 1921 to form the Imperial Bank of India. The triad had been transformed into a monolith and a giant among Indian commercial banks had emerged. The new bank took on the triple role of a commercial bank, a banker's bank and a banker to the government.

But this creation was preceded by years of deliberations on the need for a 'State Bank of India'. What eventually emerged was a 'half-way house' combining the functions of a commercial bank and a quasi-central bank.

The establishment of the Reserve Bank of India as the central bank of the country in 1935 ended the quasicentral banking role of the Imperial Bank. The latter ceased to be bankers to the Government of India and instead became agent of the Reserve Bank for the transaction of government business at centres at which the central bank was not established. But it continued to maintain currency chests and small coin depots and operate the remittance facilities scheme for other banks and the public on terms stipulated by the Reserve Bank. It also acted as a bankers' bank by holding their surplus cash and granting them advances against authorised securities. The management of the bank clearing houses also continued with it at many places where the Reserve Bank did not have offices. The bank was also the biggest tenderer at the Treasury bill auctions conducted by the Reserve Bank on behalf of the Government.

The establishment of the Reserve Bank simultaneously saw important amendments being made to the constitution of the Imperial Bank converting it into a purely commercial bank. The earlier restrictions on its business were removed and the bank was permitted to undertake foreign exchange business and executor and trustee business for the first time.

\section{Imperial Bank:}

The Imperial Bank during the three and a half decades of its existence recorded an impressive growth in terms of offices, reserves, deposits, investments and advances, the increases in some cases amounting to more than six-fold. The financial status and security inherited from its forerunners no doubt provided a firm and durable platform. But the lofty traditions of banking which the Imperial Bank consistently maintained and the high standard of integrity it observed in its operations inspired confidence in its depositors that no other bank in India could perhaps then equal. All these enabled the Imperial Bank to acquire a pre-eminent position in the Indian banking industry and also secure a vital place in the country's economic life.

When India attained freedom, the Imperial Bank had a capital base (including reserves) of Rs.11.85 crores, deposits and advances of Rs.275.14 crores and Rs.72.94 crores respectively and a network of 172 branches and more than 200 sub offices extending all over the country.

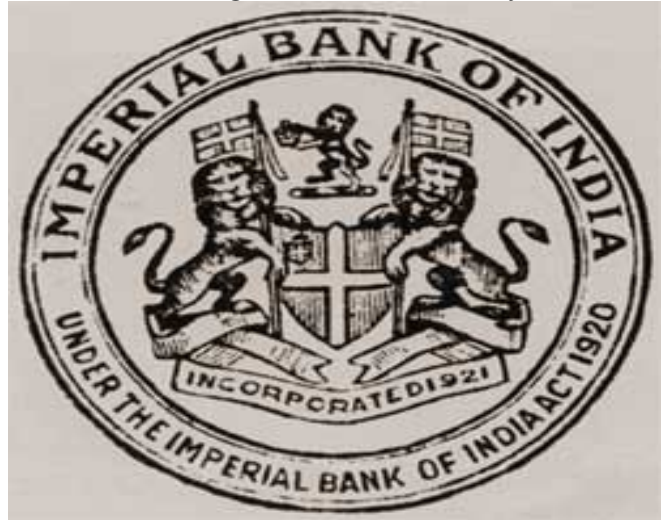

Stamp of Imperial Bank of India 


\section{First Five Year Plan:}

In 1951, when the First Five Year Plan was launched, the development of rural India was given the highest priority. The commercial banks of the country including the Imperial Bank of India had till then confined their operations to the urban sector and were not equipped to respond to the emergent needs of economic regeneration of the rural areas. In order, therefore, to serve the economy in general and the rural sector in particular, the All India Rural Credit Survey Committee recommended the creation of a state-partnered and state-sponsored bank by taking over the Imperial Bank of India, and integrating with it, the former state-owned or state-associate banks. An act was accordingly passed in Parliament in May 1955 and the State Bank of India was constituted on 1 July 1955. More than a quarter of the resources of the Indian banking system thus passed under the direct control of the State. Later, the State Bank of India (Subsidiary Banks) Act was passed in 1959, enabling the State Bank of India to take over eight former State-associated banks as its subsidiaries (later named Associates).

The State Bank of India was thus born with a new sense of social purpose aided by the 480 offices comprising branches, sub offices and three Local Head Offices inherited from the Imperial Bank. The concept of banking as mere repositories of the community's savings and lenders to creditworthy parties was soon to give way to the concept of purposeful banking subserving the growing and diversified financial needs of planned economic development. The State Bank of India was destined to act as the pacesetter in this respect and lead the Indian banking system into the exciting field of national development.

\section{ASSOCIATE BANKS}

State Bank of India has the following five Associate Banks (ABs) with controlling interest ranging from $75 \%$ to $100 \%$.

1. State Bank of Bikaner and Jaipur (SBBJ)

2. State Bank of Hyderabad (SBH)

3. State Bank of Mysore (SBM)

4. State Bank of Patiala (SBP)

5. State Bank of Travancore (SBT)

As on June 30,2011, the five ABs have a combined network of 4748 branches in India which are on core banking and 4713 ATMs networked with SBI ATMs, providing value added services to clientele.

The combined net profit of these banks increased by $10.67 \%$ over the previous year to reach Rs. 735.79 crores as on 30th June 2011. Deposits and advances grew by $12.39 \%$ and $16.32 \%$, respectively, during the year. The combined Net NPA ratio of all ABs was at $1.12 \%$ as on 30th June 2011.The highlights of performance of the five $\mathrm{ABs}$ for the quarter ended June 11 are as follows:

\begin{tabular}{|l|r|}
\hline Deposits & 317581 \\
\hline Loans & 240601 \\
\hline Investments & 97439 \\
\hline Total Assets & 378565 \\
\hline Return on Assets & $0.79 \%$ \\
\hline No. of Branches & 4748 \\
\hline
\end{tabular}

Url:

SBBJ

www.sbbjbank.com

SBH

www.sbhyd.com

SBM

www.mysorebank.com

SBP

www.sbp.co.in

SBT

www.statebankoftravancore.com

SBICI Bank Ltd (Banking Subsidiary, fully owned by SBI):

SBICI Bank Ltd has two branches, fully computerised, operating in Mumbai. The Bank recorded a net profit of Rs.0.27 crore during quarter ended June 11. Deposits, Loans and Investments were at Rs.416.89 crore, 
Rs.233.95 crore and Rs.304.40 crore, respectively, as at 30th June 2011. Return on Assets was at $0.17 \%$ while Capital Adequacy Ratio stood at $29.67 \%$ as on 30.6.2011.

\section{Current Board of Directors:}

After the end of O. P. Bhatt's reign as SBI chairman on March 31, 2011, the post was taken over by Pratip Chaudhuri, who is the former deputy managing director of the international division of SBI. As of August 4, 2011, there are twelve members in the SBI board of directors, including Subir Gokarn, who is also one of the four deputy governors of the Reserve Bank of India. The complete list of the Board members is:

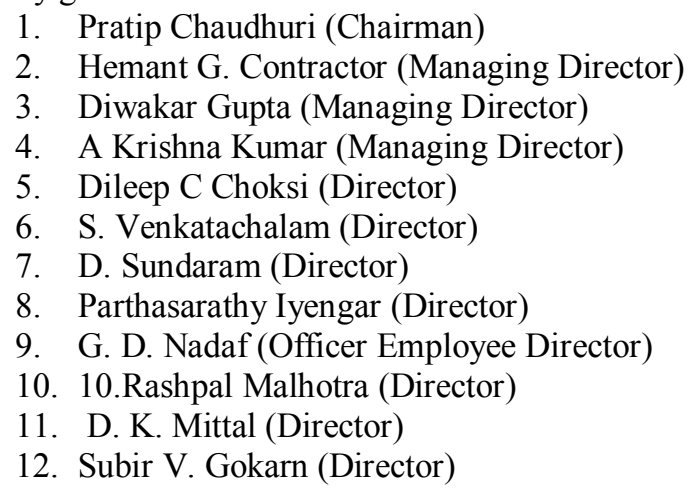

\section{Recent awards and recognitions:}

- Management Award (Runner Up) by IBA Banking Technology Awards 2010

- The Bank of the year 2009, India (won the second year in a row) by The Banker Magazine

- $\quad$ Best Bank - Large and Most Socially Responsible Bank by the Business Bank Awards 2009

- Best Bank 2009 by Business India

- The Most Trusted Brand 2009 by The Economic Times

- $\quad$ Most Preferred Bank \& Most preferred Best Online Banking Award, Best Customer Initiative Award \& Best Risk Home loan provider by CNBC

- Visionaries of Financial Inclusion By FINO

- Technology Bank of the Year by IBA Banking Technology Awards

\section{SERVICES:}

\section{ONLINE TRADING}

State Bank of India (SBI) now introduces you to a State-Of-Art broking predominantly to cater to every broking need and offers a truly world class experience of online investing -anyplace, anytime. Buying and selling of shares is now just a click away.

Our value proposition is based on Unmatched Expertise, State-Of-Art Technology And Operational Ease that will redefine the way india trades. With us you have the power of research expertise to aid you in making the right decisions, operational ease allowing you to seamlessly execute your transactions, timely advice that helps you pick the right opportunities and a customized trading experience to suit your needs and demands. So go ahead and enjoy yourfast, easy and hassle-free trading experience with the india's largest bank.

State Bank of India in alliance with SBICap Securities Limited and Motilal Oswal Securities Limited now offers you an online trading account which will let you trade from the comfort of your home or office either through the internet. This service provides you with a 3 -in 1 account which is an integrated platform of savings bank $\mathrm{a} / \mathrm{c}$, demat $\mathrm{a} / \mathrm{c}$ and an online trading a/c to give you a convenient and paper free trading experience under one roof.

\section{ATM SERVICES: \\ STATE BANK NETWORKED ATM SERVICES}

State Bank offers you the convenience of over 26,000 ATMs in India, the largest network in the country and continuing to expand fast! This means that you can transact free of cost at the ATMs of State Bank Group (This includes the ATMs of State Bank of India as well as the Associate Banks - namely, State Bank of Bikaner \& Jaipur, State Bank of Hyderabad, State Bank of Mysore, State Bank of Patiala, and State Bank of Travancore) and wholly owned subsidiary viz. SBI Commercial and International Bank Ltd., using the State Bank ATM-cum-Debit (Cash Plus) card. 


\section{KINDS OF CARDS ACCEPTED AT STATE BANK ATMs}

Besides all cards of State Bank of India, State Bank ATM-Cum-Debit Card and State Bank International ATMCum-Debit Cards following cards are also accepted at State Bank ATMs: -

1) State Bank Credit Card

2) Cards issued by other banks displaying Maestro, Master Card, Cirrus, VISA and VISA Electron logos

3) All Debit/ Credit Cards issued by any bank outside India displaying Maestro, Master Card, Cirrus, VISA and VISA Electron logos

\section{State Bank ATM-cum-Debit (State Bank Cash plus) Card:}

India's largest bank is proud to offer you unparalleled convenience viz. State Bank ATM-cum-Debit (Cash Plus) card. With this card, there is no need to carry cash in your wallet. You can now withdraw cash and make purchases anytime you wish to with your ATM-cum-Debit Card.

INTERNET BANKING:

\section{WELCOME ABOARD}

www.onlinesbi.com, the Internet banking portal of our bank, enables its retail banking customers to operate their accounts from anywhere anytime, removing the restrictions imposed by geography and time. It's a platform that enables the customers to carry out their banking activities from their desktop, aided by the power and convenience of the Internet.

Using Internet banking services, you can do the following normal banking transactions online:

Funds transfer between own accounts.

Third party transfers to accounts maintained at any branch of SBI

Group Transfers to accounts in State Bank Group

Inter Bank Transfers to accounts with other Banks

Online standing instructions for periodical transfer for the above

Credit PPF accounts across branches

Request for Issue of Demand Draft

Request for opening of new accounts

Request for closure of Loan Accounts

Request for Issue of Cheque Book

\section{FOREIGN INWARD REMITTANCE:}

Sending remittances to India for credit to your account with our bank or for your family is very simple and convenient with our wide foreign offices network and correspondent banking arrangement with about 600 banks worldwide. Wherever in the world you may be, there is our office or a bank having corresponding banking arrangement with our bank to provide facilities of remittances.

You could use any of the following ways to send the remittances.

SBI Express Remit Facility

Demand Drafts in Rupees

Telegraphic/wire transfers

Personal cheques/ travelers cheques (in person only)/ DDs in foreign currency

\section{SAFE DEPOSIT LOCKER:}

For the safety of your valuables, we offer safe deposit locker facility at a large number of our branches. There is a nominal annual rent, which depends on the size of the locker and the centre at which the branch is located. The rent is payable in advance for the Financial Year. A copy of the locker agreement regarding operation of the locker can be provided to the locker hirer at the time of allotment of the locker.

It is always beneficial to avail the benefits of nomination facility/ survivorship clause provided to locker-hirers. The major advantage of availing these facilities is that in the event of unfortunate death of one of the joint locker-hirer, the right to the contents of the locker does not automatically devolve on the surviving joint locker-hirer/ nominee (s), unless there is a survivorship clause/ nomination.

\section{Sampling Procedure:}

\section{Research Methodology and Design \\ Research Methodology}

\section{Data Collection:}

Data collection is a term used to describe a process of preparing and collecting data, for example, as part of a process improvement or similar project. The purpose of data collection is to obtain information to keep on 
record, to make decisions about important issues, to pass information on to others. Primarily, data are collected to provide information regarding a specific topic.

Primary Data:

In primary data collection, you collect the data yourself using methods such as interviews and questionnaires. The key point here is that the data you collect is unique to you and your research and, until you publish, no one else has access to it. There are many methods of collecting primary data and the main methods include:

- questionnaires

- interviews

- focus group interviews

- observation

- case-studies

- diaries

- critical incidents

- portfolios.

Secondary Data:

All methods of data collection can supply quantitative data (numbers, statistics or financial) or qualitative data (usually words or text). Quantitative data may often be presented in tabular or graphical form. Secondary data is data that has already been collected by someone else for a different purpose to yours. For example, this could mean using:

- data collected by a hotel on its customers through its guest history system

- data supplied by a marketing organisation

- annual company reports

- government statistics.

Research Design:

Research design is considered as a "blueprint" for research, dealing with at least four problems: which questions to study, which data are relevant, what data to collect, and how to analyze the results. The best design depends on the research question as well as the orientation of the researcher.

Type of Research:

Explanatory research is research conducted in order to explain any behaviour in the market. It could be done through using questionnaires, group discussions, interviews, random sampling, etc.

Type of survey:

Simple random sample technique tools.

Sample size:

Samples of 120 customers for collecting the data.

\section{Research Instrument:}

\section{Questionnaires.}

The interview guide was used especially to make the study complete and objective. The information gathered in the personal interview methods, are questions that are answered in objective type.

\section{Bar Charts:}

A bar chart or bar graph is a chart with rectangular bars with lengths proportional to the values that they represent. The bars can be plotted vertically or horizontally.Bar charts are used for marking clear data which has discrete values. Some examples of discontinuous data include 'shoe size' or 'eye color', for which a bar chart is appropriate.

\section{Spearman's Rank Correlation:}

In statistics, Spearman's rank correlation coefficient or Spearman's rho, named after Charles Spearman and often denoted by the Greek letter $\rho_{(\text {rho }) \text { or as }} r_{s}$, is a non-parametric measure of statistical dependence between two variables. It assesses how well the relationship between two variables can be described using a monotonic function. If there are no repeated data values, a perfect Spearman correlation of +1 or -1 occurs when each of the variables is a perfect monotone function of the other. The Spearman correlation coefficient is defined as the Pearson correlation coefficient between the ranked variables.

$$
\rho=\frac{\sum_{i}\left(x_{i}-\bar{x}\right)\left(y_{i}-\bar{y}\right)}{\sqrt{\sum_{i}\left(x_{i}-\bar{x}\right)^{2} \sum_{i}\left(y_{i}-\bar{y}\right)^{2}}} .
$$

\section{Sample Units:}

The Respondents are different categories with respect to their occupations.

5.Data Processing: 
It was done with almost case to ensure valid and reliable results of Data analysis. The tabulation was made depending on the nature and size of the data obtained. Depending on the nature of the questions, the data was processed using percentage analysis and weighted average to consolidate the results.

\section{Percentage Analysis:}

Percentage analysis is used to find out the percentage value of all the entire different questions used in finding comparison between two or more series of data.

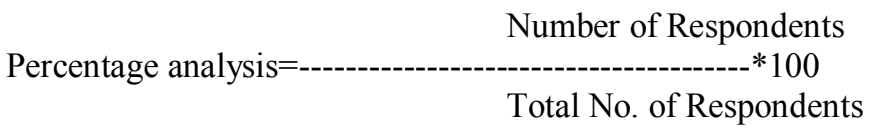

Standard Deviation:

$$
\sigma=\sqrt{\mathrm{E}\left[(X-\mu)^{2}\right]}=\sqrt{\mathrm{E}\left[X^{2}\right]-(\mathrm{E}[X])^{2}} .
$$

- The study has been conducted on behalf of "STATE BANK OF INDIA".

- The study is confined to the kavali region.

- The study covers the service providers and users of "STATE BANK OF INDIA".

- The study has put forward the Customers as well as acceptability behavior for the services.

- The scope of the study is to find out the "Customer Satisfaction".

\section{Need for study}

- Customer Satisfaction is very essential for every Service to survive in the market.

- Customer Satisfaction could help the business by placing future demand to the company.

- Customer Satisfaction gives passing the words of mouth to other potential customers.

- Customer Satisfaction is very Important for the company to take care of the customers and make them to satisfy.

\section{Objectives of the Study}

- To study the Satisfaction of customers towards the "STATE BANK OF INDIA".

- To Identify the factors that influences the customer behavior of "STATE BANK OF INDIA".

- To Evaluate the merits and De merits of "STATE BANK OF INDIA".

- To give the appropriate suggestions for the improvement of "STATE BANK OF INDIA".

- Study is confined to kavali A.P.state in INDIA only.

\section{Limitations of the study}

- The sample size is 200 hence finding cannot be generalized.

- The period of the study is limited 7 weeks only.

- It was difficult to know whether the respondents are truly given the exact information.

- Customer preferences and opinions are supposed to change from time to time.

\section{Review of Literature}

\section{Review of Literature}

It is seen as a key performance indicator within business and is often part of a Balanced Scorecard. In a competitive marketplace where businesses compete for customers, customer satisfaction is seen as a key differentiator and increasingly has become a key element of business strategy.

"Within organizations, customer satisfaction ratings can have powerful effects. They focus employees on the importance of fulfilling customers' expectations. Furthermore, when these ratings dip, they warn of problems that can affect sales and profitability. ... These metrics quantify an important dynamic. When a brand has loyal customers, it gains positive word-of-mouth marketing, which is both free and highly effective."

Therefore, it is essential for businesses to effectively manage customer satisfaction. To be able do this, firms need reliable and representative measures of satisfaction.

"In researching satisfaction, firms generally ask customers whether their product or service has met or exceeded expectations. Thus, expectations are a key factor behind satisfaction. When customers have high expectations and the reality falls short, they will be disappointed and will likely rate their experience as less than 
satisfying. For this reason, a luxury resort, for example, might receive a lower satisfaction rating than a budget motel — even though its facilities and service would be deemed superior in 'absolute' terms."

The importance of customer satisfaction diminishes when a firm has increased bargaining power. For example, cell phone plan providers, such as AT\&T and Verizon, participate in an industry that is an oligopoly, where only a few suppliers of a certain product or service exist. As such, many cell phone plan contracts have a lot of fine print with provisions that they would never get away if there were, say, a hundred cell phone plan providers, because customer satisfaction would be way too low, and customers would easily have the option of leaving for a better contract offer.

\section{Purpose:}

Their principal use is twofold:"

1. "Within organizations, the collection, analysis and dissemination of these data send a message about the importance of tending to customers and ensuring that they have a positive experience with the company's goods and services."

2. "Although sales or market share can indicate how well a firm is performing currently, satisfaction is perhaps the best indicator of how likely it is that the firm's customers will make further purchases in the future.

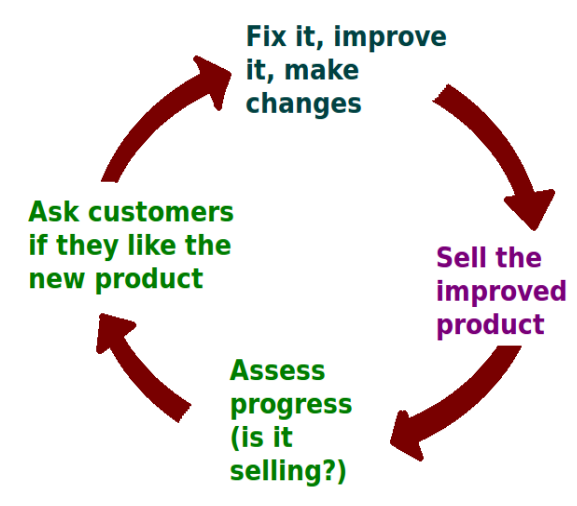

\section{Construction:}

"Customer satisfaction is measured at the individual level, but it is almost always reported at an aggregate level. It can be, and often is, measured along various dimensions. A hotel, for example, might ask customers to rate their experience with its front desk and check-in service, with the room, with the amenities in the room, with the restaurants, and so on. Additionally, in a holistic sense, the hotel might ask about overall satisfaction 'with your stay.'

The usual measures of customer satisfaction involve a survey with a set of statements using a Likert Technique or scale. The customer is asked to evaluate each statement and in term of their perception and expectation of performance of the organization being measured. Their satisfaction is generally measured on a five-point scale.

\begin{tabular}{|c|c|c|c|c|}
\hline $\begin{array}{c}\text { Very } \\
\text { dissatisfied }\end{array}$ & $\begin{array}{c}\text { 8omewhet } \\
\text { dlsontafled }\end{array}$ & $\begin{array}{c}\text { Neither } \\
\text { satisfied nor } \\
\text { dissatisfied }\end{array}$ & $\begin{array}{c}\text { 8omewhet } \\
\text { sattefiod }\end{array}$ & $\begin{array}{c}\text { Very } \\
\text { satisfied }\end{array}$ \\
\hline 1 & $\mathbf{2}$ & 3 & $\mathbf{4}$ & 5 \\
\hline
\end{tabular}

Customer satisfaction is an ambiguous and abstract concept and the actual manifestation of the state of satisfaction will vary from person to person and product/service to product/service. The state of satisfaction depends on a number of both psychological and physical variables which correlate with satisfaction behaviors such as return and recommend rate. The level of satisfaction can also vary depending on other options the customer may have and other products against which the customer can compare the organization's products.

\section{Methodologies:}

American Customer Satisfaction Index (ACSI) is a scientific standard of customer satisfaction. Academic research has shown that the national ACSI score is a strong predictor of Gross Domestic Product (GDP) growth, and an even stronger predictor of Personal Consumption Expenditure (PCE) growth. On the microeconomic level, academic studies have shown that ACSI data is related to a firm's financial performance in terms of return on investment(ROI), sales, long-term firm value (Tobin's $q$, cash flow, cash flow volatility, human capital performance, portfolio returns, debt financing, risk, and consumer spending.

The Kano model is a theory of product development and customer satisfaction developed in the 1980s by Professor Noriaki Kano that classifies customer preferences into five categories: Attractive, One-Dimensional, 
Must-Be, Indifferent, Reverse. The Kano model offers some insight into the product attributes which are perceived to be important to customers.

\section{Customer service system:}

Customer service is the provision of service to customers before, during and after a purchase. According to Turban et al. (2002), "Customer service is a series of activities designed to enhance the level of customer satisfaction - that is, the feeling that a product or service has met the customer expectation."

Its importance varies by products, industry and customer; defective or broken merchandise can be exchanged, often only with a receipt and within a specified time frame. Retail stores often have a desk or counter devoted to dealing with returns, exchanges and complaints, or will perform related functions at the point of sale; the perceived success of such interactions being dependent on employees "who can adjust themselves to the personality of the guest," according to Micah Solomon quoted in Inc. Magazine.

From the point of view of an overall sales process engineering effort, customer service plays an important role in an organization's ability to generate income and revenue. From that perspective, customer service should be included as part of an overall approach to systematic improvement. A customer service experience can change the entire perception a customer has of the organization.

\section{Data Analysis and Interpretation}

Table Shows Rank Correlation between Core Banking services and Online Banking services:

\begin{tabular}{|c|c|c|c|c|c|c|}
\hline Respondents & $\begin{array}{c}\text { Core Banking } \\
\text { Services(x) }\end{array}$ & $\begin{array}{c}\text { Online Banking } \\
\text { Services(y) }\end{array}$ & Rank x & Rank y & (d) & $\mathrm{d} 2$ \\
\hline Students & 10 & 12 & 7 & 6 & 1 & 1 \\
\hline Govt.Employees & 30 & 14 & 1 & 4 & -3 & 9 \\
\hline Businessmen & 8 & 13 & 8 & 5 & 3 & 9 \\
\hline Agriculture & 13 & 17 & 5 & 2 & 3 & 9 \\
\hline Rtd.Employees & 17 & 16 & 2 & 3 & -1 & 1 \\
\hline Housewives & 12 & 10 & 6 & 7 & -1 & 1 \\
\hline Workers & 14 & 8 & 4 & 8 & -4 & 16 \\
\hline Pvt.Employees & 16 & 30 & 3 & 1 & 2 & 4 \\
\hline & & & & & & $\sum \mathrm{d} 2=50$ \\
\hline
\end{tabular}

Spearman's rank correlation equation:

$$
\rho=1-\frac{6 \sum d_{i}^{2}}{n\left(n^{2}-1\right)}
$$

$1-\underline{6 * 50}=\mathbf{0 . 4 0 4 7}$

$$
8 \overline{(64-1)}
$$

INFERENCE:

There is a positive Correlation between core banking respondents and online banking respondents with the value of 0.4047

Table shows different respondents with respect to their occupations:

\begin{tabular}{|c|c|c|}
\hline Occupations & Respondents & Percentage \\
\hline Students & 15 & 12.50 \\
\hline Govt.employees & 15 & 12.50 \\
\hline Pvt.employees & 15 & 12.50 \\
\hline Business man & 15 & 12.50 \\
\hline workers & 15 & 12.50 \\
\hline Agriculture & 15 & 12.50 \\
\hline Housewives & 15 & 12.50 \\
\hline Rtd.employees & 15 & 12.50 \\
\hline & & \\
\hline Total & 120 & 100.00 \\
\hline
\end{tabular}




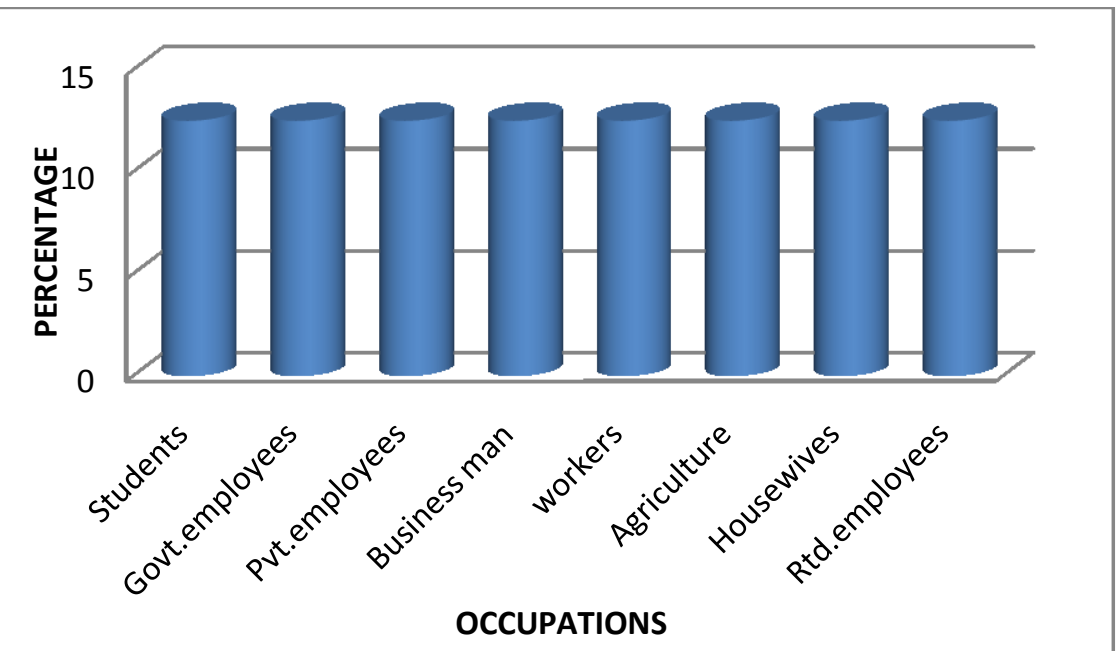

INFERENCE:

There are different types of respondents had being taken in each of them were same number, I, e...15 members.

Table shows the opening procedure of an account:

\begin{tabular}{|c|c|c|}
\hline Option & Respondents & Percentage \\
\hline Yes & 112 & 93.00 \\
\hline no & 4 & 3.00 \\
\hline Cannot say & 4 & 3.00 \\
\hline Total & 120 & 100.00 \\
\hline
\end{tabular}

GRAPH:2

INFERENCE:

From the above information on core banking facility of S.B.I. by asking to respondents, $93 \%$ of the respondents prefer to yes, $3 \%$ of respondents prefer no and only $3 \%$ were not aware.

Table shows alternative S.B.I. Bank:

\begin{tabular}{|c|c|c|}
\hline Options & Respondents & Percentage \\
\hline yes & 55 & 46.00 \\
\hline no & 35 & 29.00 \\
\hline not aware & 30 & 25.00 \\
\hline Total & 120 & \\
\hline
\end{tabular}


GRAPH:3

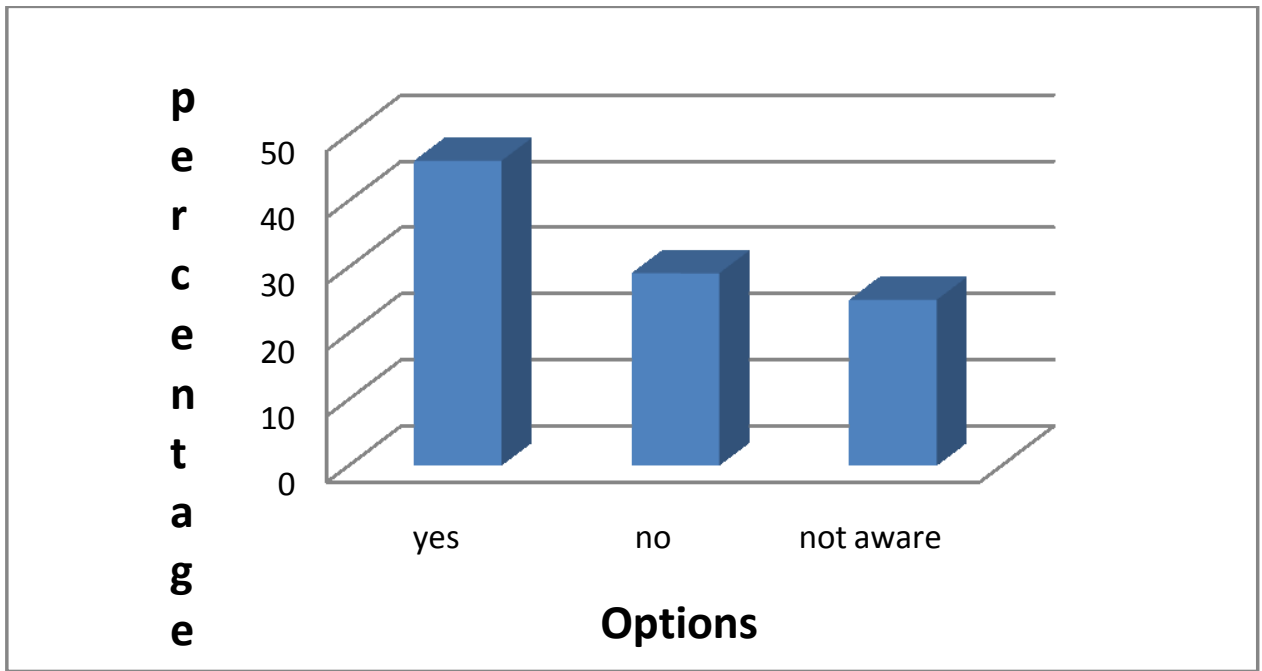

INFERNCE:

From the above information on choosing alternate of S.B.I. by asking to respondents, $46 \%$ of the respondents prefer to yes, $29 \%$ of respondents prefer no and only $23 \%$ were not aware.

Table shows age of the respondents:

\begin{tabular}{|c|c|c|}
\hline Ages & Respondents & Percentage \\
\hline $19-25$ & 30 & 25.00 \\
\hline $25-35$ & 30 & 25.00 \\
\hline $35-50$ & 30 & 25.00 \\
\hline $50>$ above & 30 & 25.00 \\
\hline & & 100.00 \\
\hline Total & 120 & \\
\hline
\end{tabular}

GRAPH:4

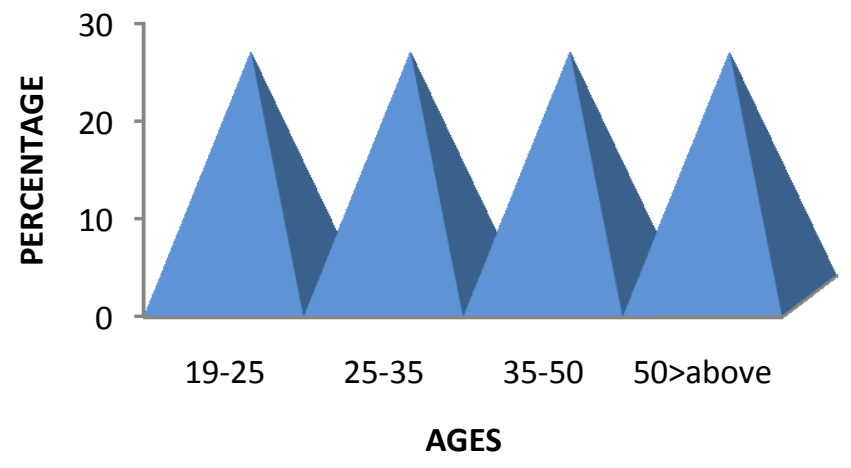

INFERENCE:

From the above information all the respondents were at same number, they categorized in 4 divisions with respect to their ages 
Table shows Types of accounts owned by customers:

\begin{tabular}{|c|c|c|}
\hline Type of account & Respondents & Percentage \\
\hline Current a/c & 15 & 13.00 \\
\hline Saving a/c & 80 & 67.00 \\
\hline Loan a/c & 10 & 8.00 \\
\hline Demat a/c & 5 & 4.00 \\
\hline Credit Card & 10 & 8.00 \\
\hline & & \\
\hline Total & 120 & 100.00 \\
\hline
\end{tabular}

GRAPH:5

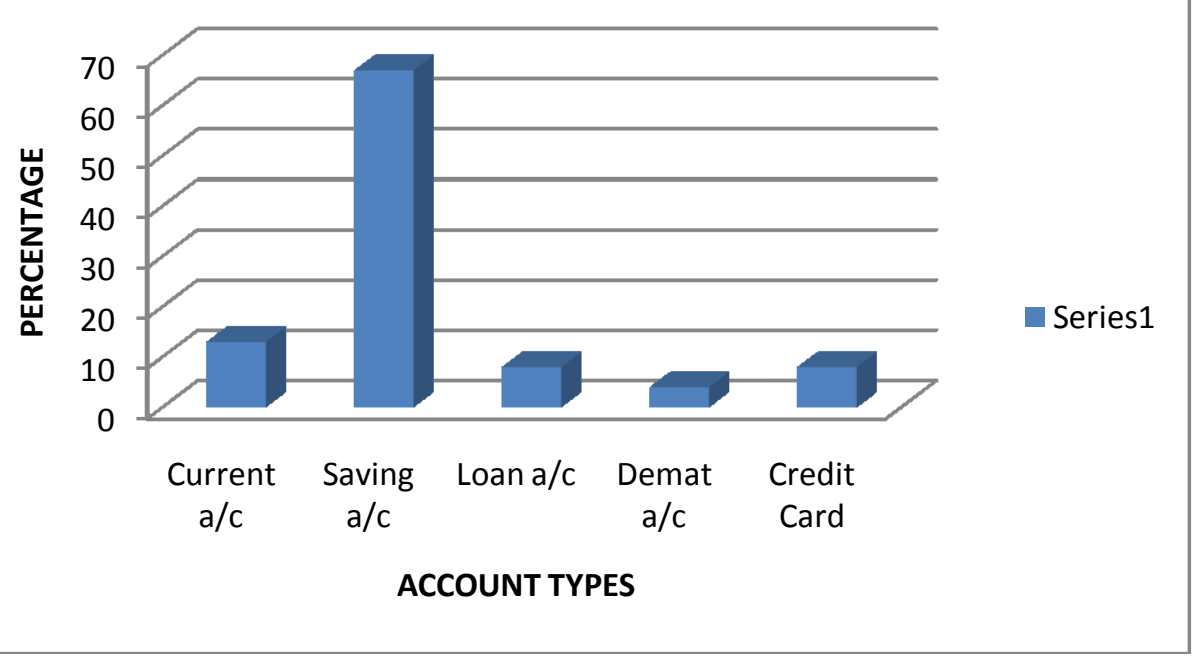

INFERENCE:

Majority of the respondents having savings a/c, next follows the Current, Loan, Demat, Credit Card a/c's.

Table shows Core Banking Facility:

\begin{tabular}{|c|c|c|}
\hline Options & Respondents & Percentage \\
\hline Yes & 78 & 65.00 \\
\hline No & 30 & 25.00 \\
\hline Not aware & 12 & 10.00 \\
\hline Total & & 100.00 \\
\hline
\end{tabular}

GRAPH:6

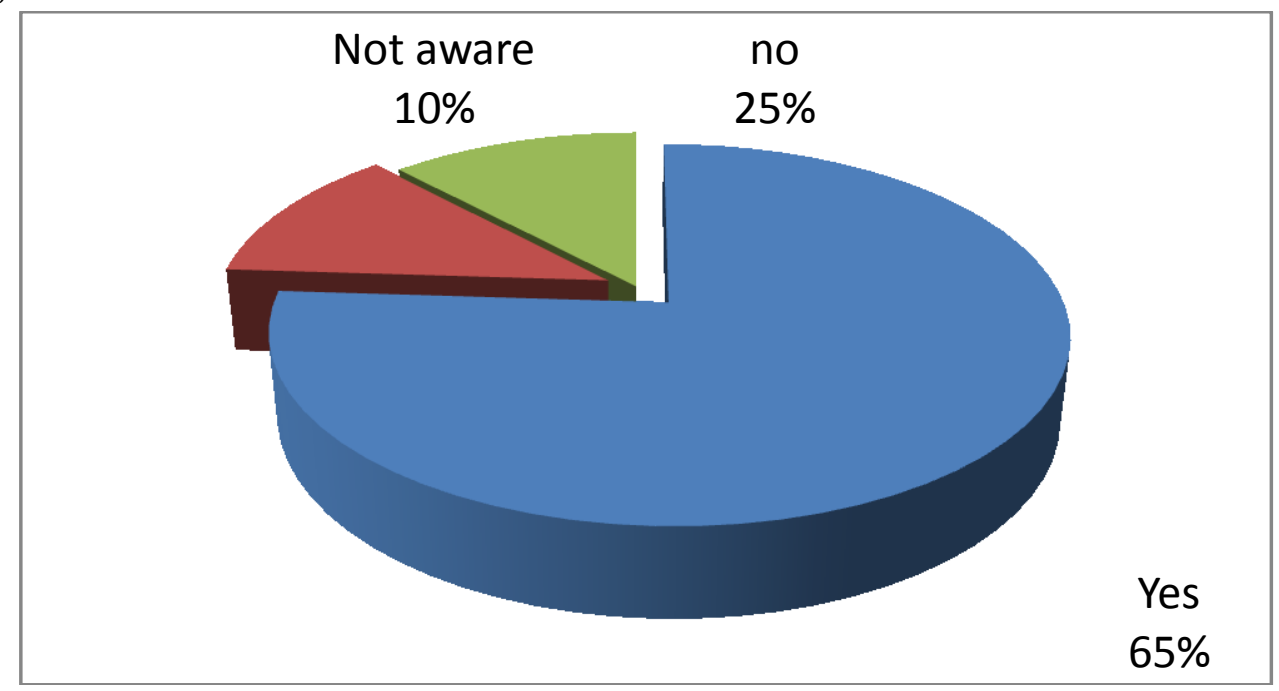




\section{INFERENCE:}

From the above information on core banking facility of S.B.I. by asking to respondents, $65 \%$ of the respondents prefer to yes, $25 \%$ of respondents prefer no and only $10 \%$ were not aware.

Table shows competitive interest provided by S.B.I.:

\begin{tabular}{|c|c|c|}
\hline Options & Respondents & Percentage \\
\hline Yes & 68 & 57.00 \\
\hline No & 28 & 23.00 \\
\hline Not aware & 24 & 20.00 \\
\hline Total & 120 & 100.00 \\
\hline
\end{tabular}

GRAPH:7

\section{INFERENCE:}

From the above information on SERVICE CHARGES of S.B.I. by asking to respondents, $57 \%$ of the respondents prefer to yes, $23 \%$ of respondents prefer no and only $20 \%$ were not aware

Table shows on an extra charge for not maintaining minimum balance:

\begin{tabular}{|c|c|c|}
\hline Options & Respondents & Percentage \\
\hline Yes & 25 & 21.00 \\
\hline No & 75 & 63.00 \\
\hline Not aware & 20 & 16.00 \\
\hline Total & & 100.00 \\
\hline
\end{tabular}

GRAPH:8

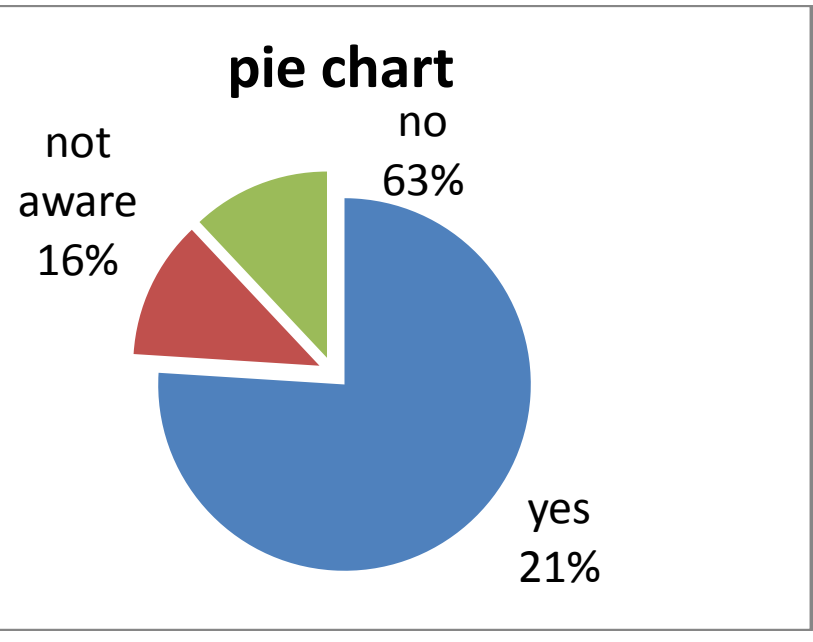


From the above information $63 \%$ were says no, $21 \%$ were says yes and $16 \%$ of the respondents have no idea about it.

Table shows opening of an account:

\begin{tabular}{|c|c|c|}
\hline Options & Respondents & Percentage \\
\hline Yes & 92 & 76.00 \\
\hline No & 14 & 12.00 \\
\hline Not aware & 14 & 12.00 \\
\hline Total & & 100.00 \\
\hline
\end{tabular}

GRAPH:9

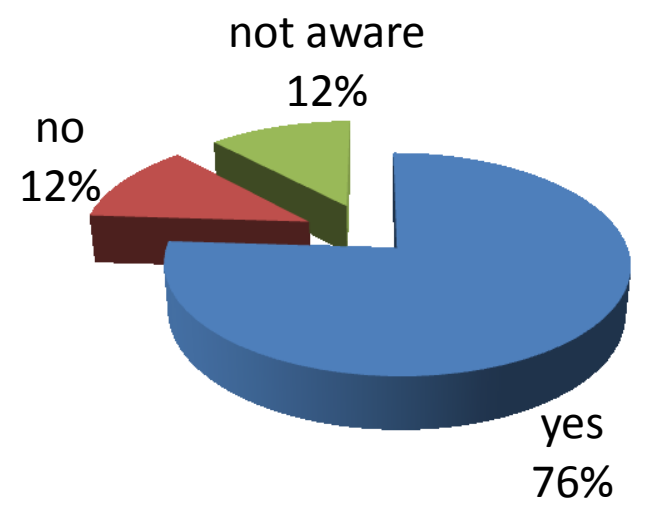

INFERENCE:

From the above information on OPENING OF AN ACCOUNT in S.B.I. by asking to respondents, 76\% of the respondents prefer to yes, $12 \%$ of respondents prefer no and only $12 \%$ were not aware.

Table Shows the S.B.I. providing all Banking needs:

\begin{tabular}{|c|c|c|}
\hline Options & Respondents & Percentage \\
\hline Yes & 110 & 91.60 \\
\hline No & 5 & 4.20 \\
\hline Not Aware & 5 & 4.20 \\
\hline Total & 120 & 100.00 \\
\hline
\end{tabular}

GRAPH: 10

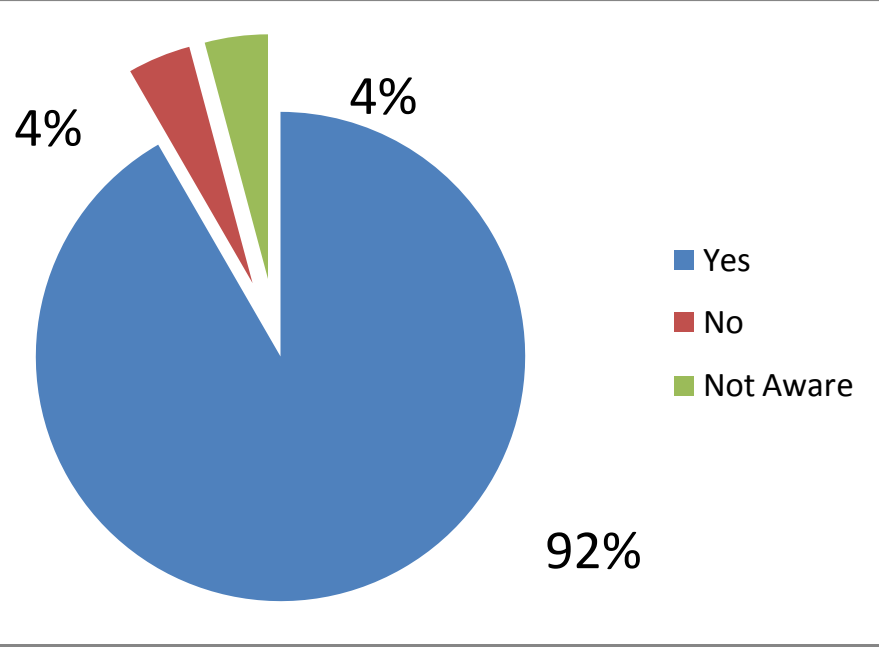


INFERENCE:

From the above information $92 \%$ of the respondents were agreed to S.B.I. provides all banking needs, $2 \%$ of the respondents says "no" And 2\% of the respondents says "not aware" regarding the information.

Table Shows S.B.I. more given facilities to customers:

\begin{tabular}{|c|c|c|}
\hline Types of Facilities & Respondents & Percentage \\
\hline Loans & 50 & 42.00 \\
\hline Overdrafts & 25 & 20.00 \\
\hline A.T.M. & 45 & 38.00 \\
\hline Total & 120 & 100.00 \\
\hline
\end{tabular}

GRAPH:11

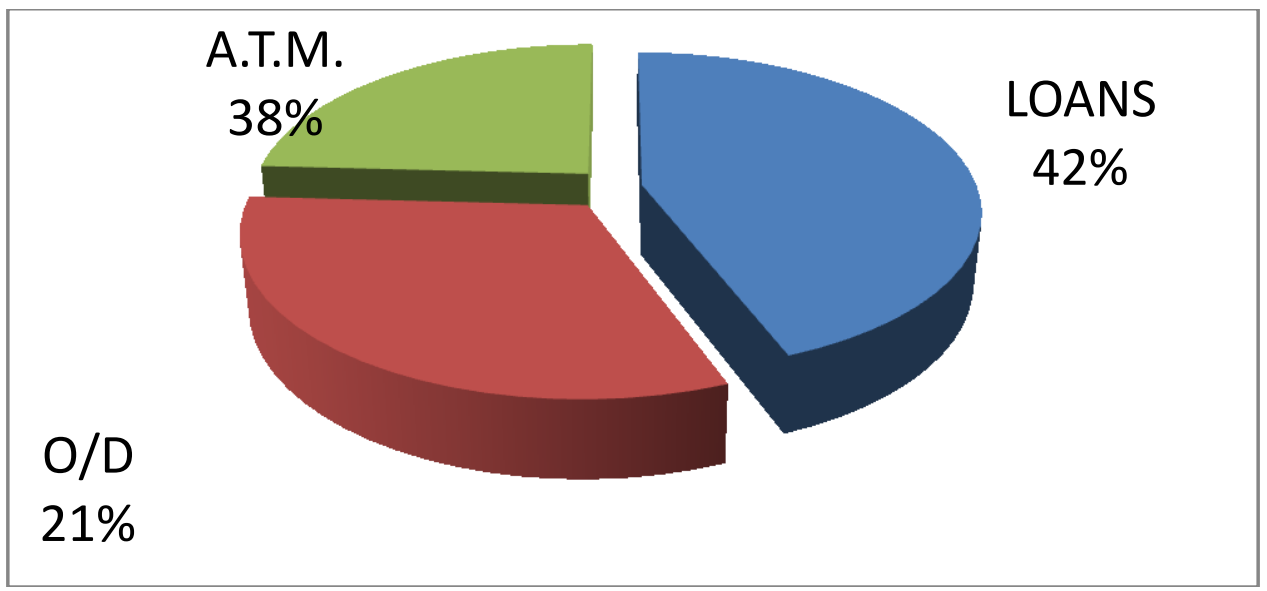

INFERENCE:

From the above information $42 \%$ of the respondents gave their Choice to loans, $38 \%$ gave on A.T.M. facilities and $21 \%$ were to Over drafts facilities.

Table Shows recreation facilities of S.B.I. Bank:

\begin{tabular}{|c|c|c|}
\hline Options & Respondents & Percentage \\
\hline Yes & 53 & 44.00 \\
\hline No & 38 & 32.00 \\
\hline Not aware & 29 & 24.00 \\
\hline Total & 120 & 100.00 \\
\hline
\end{tabular}

GRAPH:12

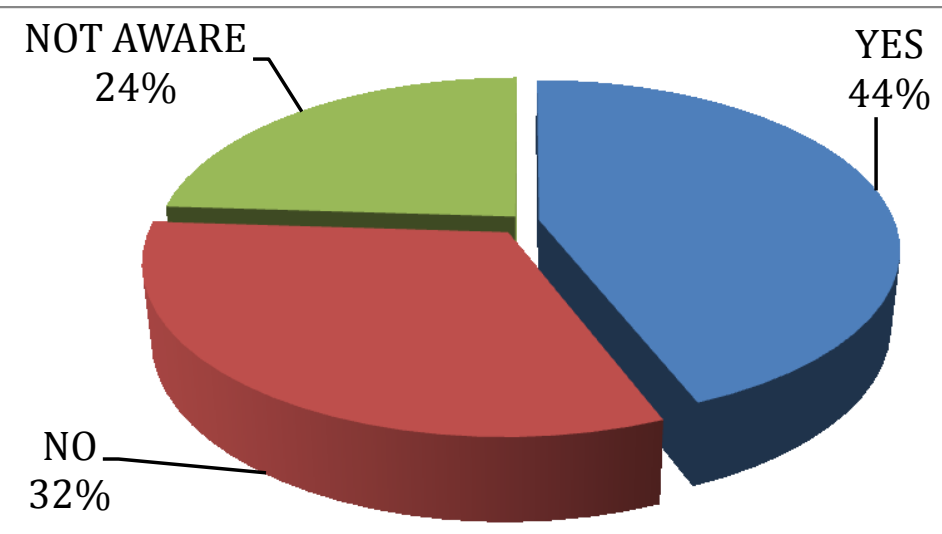


From the above information shows $44 \%$ of the respondents were Agreed ,32\% of the respondents were not agreed and 24\% of the Respondents does not know about it.

In STOCK EXCHANGE:

Table shows Information to customers about display of S.B.I. shares

\begin{tabular}{|c|c|c|}
\hline Options & Respondents & Percentage \\
\hline Yes & 45 & 38.00 \\
\hline No & 32 & 26.00 \\
\hline Not aware & 43 & 36.00 \\
\hline Total & & 100.00 \\
\hline
\end{tabular}

GRAPH: 13

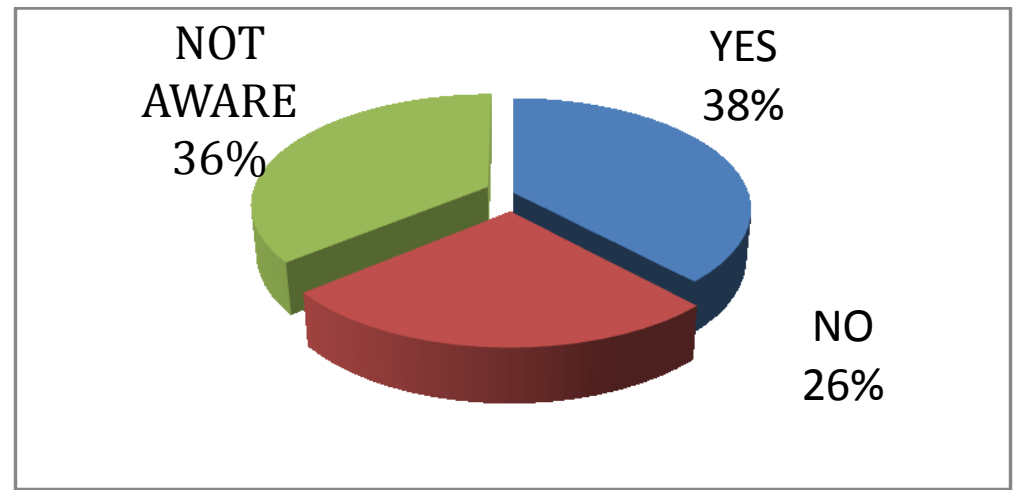

\section{INFERENCE:}

From the above information regarding the display of S.B.I shares in stock exchange to customers is as $38 \%$ of the respondents were known, $26 \%$ were says no and $36 \%$ were not aware about it.

Table shows Feedback on over all services:

\begin{tabular}{|c|c|c|}
\hline Particulars & Respondents & Percentage \\
\hline Excellent & 15 & 13.00 \\
\hline Very Good & 45 & 38.00 \\
\hline Good & 30 & 25.00 \\
\hline Average & 25 & 20.00 \\
\hline Poor & 5 & 4.00 \\
\hline & & 100.00 \\
\hline Total & 120 & \\
\hline
\end{tabular}

GRAPH: 14

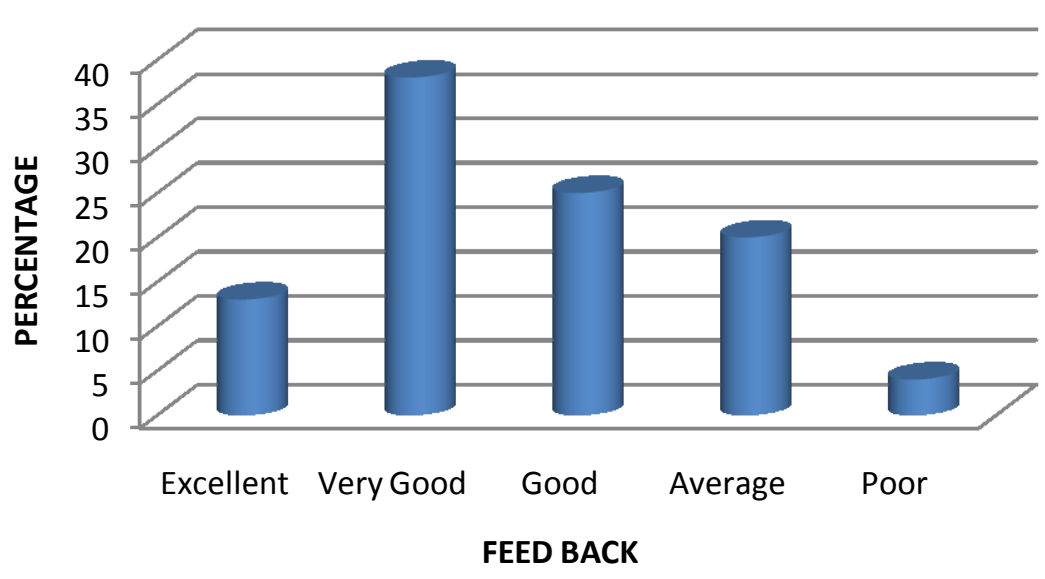


INFERENCE:

From the above information regarding feed back on overall service on bank, majority $38 \%$ respondents gave very good, $25 \%$ were gave good, $20 \%$ were gave average, $13 \%$ were gave excellent and only $4 \%$ respondents gave poor on performance.

Table shows RATING SCALE on preference of services:

\begin{tabular}{|c|c|c|c|}
\hline Preferences & Ranks & Respondents & Percentage \\
\hline personalized & 1 & 70 & 58.34 \\
\hline wide branch & 3 & 10 & 8.34 \\
\hline customer service & 4 & 10 & 8.34 \\
\hline computerized & 5 & 10 & 8.34 \\
\hline core banking & 2 & 20 & 16.64 \\
\hline Total & & & 100.00 \\
\hline
\end{tabular}

GRAPH: 15

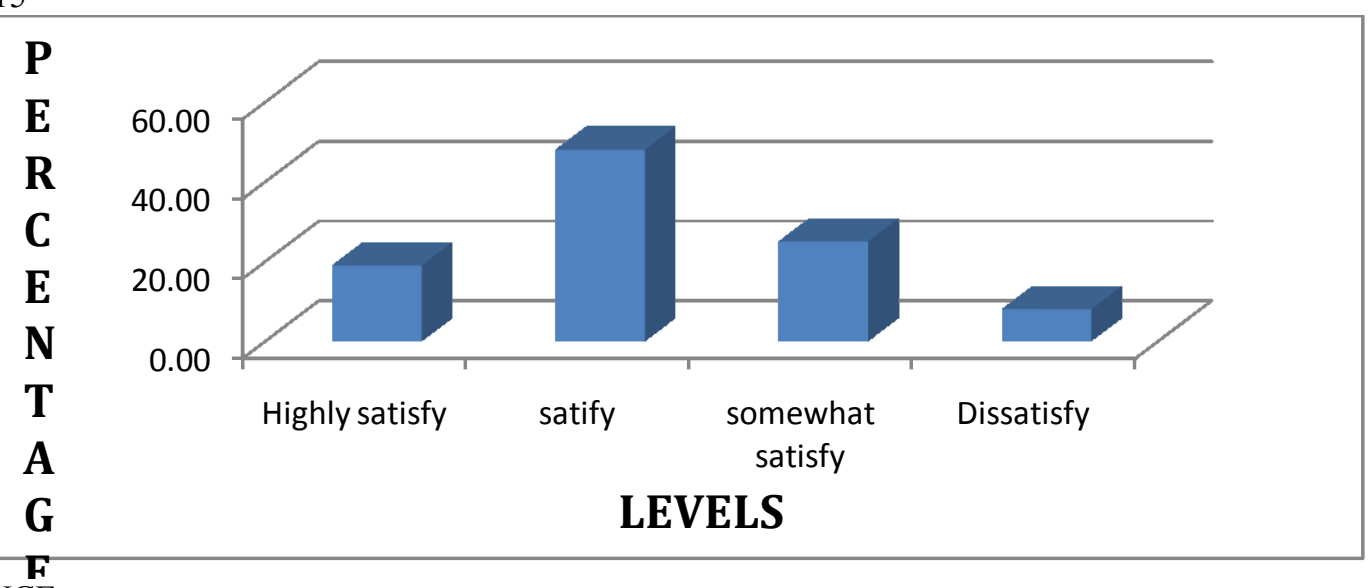

INFERENCE:

Based on the Ranking given by respondents majority for personalized at $70 \%$, w.branch, c.service, computerized as $10 \%$ and $20 \%$ given to core banking service.

Table shows satisfaction level of customers:

\begin{tabular}{|c|c|c|}
\hline Preferences & Respondents & Percentage \\
\hline Highly satisfy & 23 & 19.00 \\
\hline satisfy & 58 & 48.00 \\
\hline somewhat satisfy & 30 & 25.00 \\
\hline Dissatisfy & 9 & 8.00 \\
\hline & & 100.00 \\
\hline
\end{tabular}

GRAPH:16

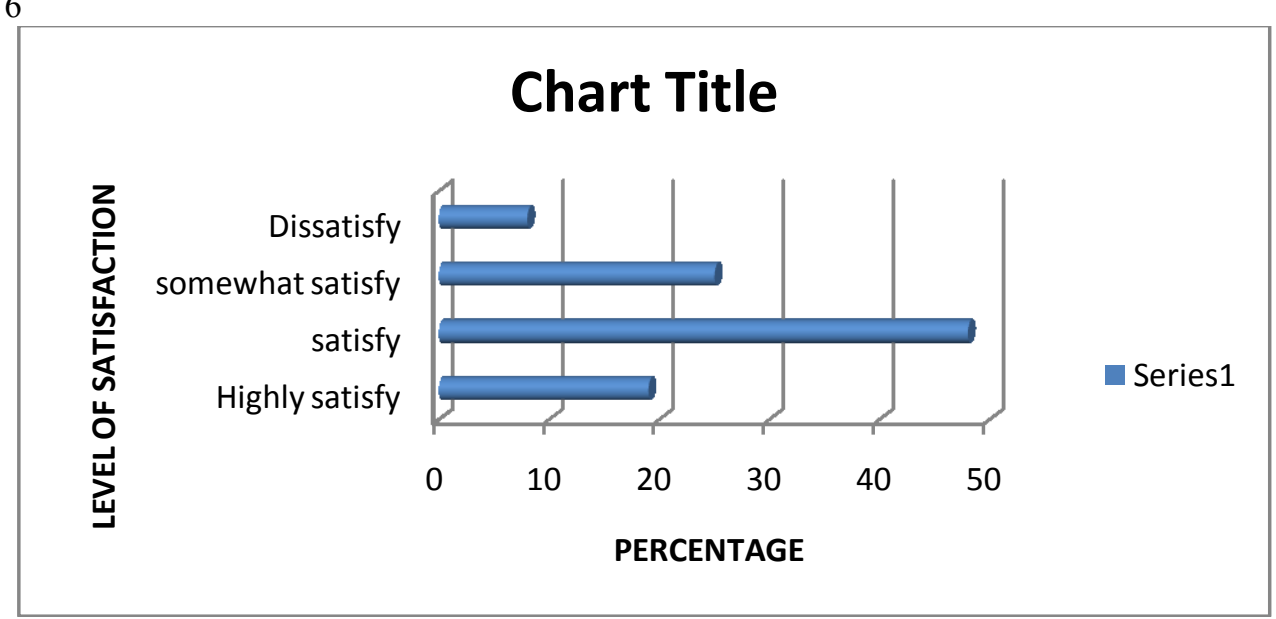


INFERENCE:

From the above information regarding feed back on overall service on bank, majority $48 \%$ respondents gave satisfy, $19 \%$ were gave very satisfy, $25 \%$ were gave some what satisfy, $8 \%$ were gave Dissatisfy.

Table Shows Standard Deviation of Respondents on Feedback:

\begin{tabular}{|c|c|c|}
\hline Particulars & Respondents(x) & $(\mathrm{x})$ \\
\hline Excellent & 15 & 225 \\
\hline Very Good & 45 & 2025 \\
\hline Good & 30 & 900 \\
\hline Bad & 25 & 625 \\
\hline Very Bad & 5 & 25 \\
\hline & & $\sum \mathrm{X} 2=3800$ \\
\hline Total & $\sum \mathrm{X}=120$ & \\
\hline
\end{tabular}

Standard Deviation:

$$
\begin{aligned}
& 0=\sqrt{\mathrm{E}\left[\left(\mathrm{X}-\mu^{2}\right)^{2}\right.}=\sqrt{\left.\left.\mathrm{E}\left[\mathrm{S}^{2}\right]-(\mathrm{E}] \mathrm{S}\right]\right)^{2}}, \\
\Sigma & =\sqrt{ } 760-576 \\
= & \sqrt{ } 184 \\
= & 13.56
\end{aligned}
$$

INFERENCE:

From the above information it is denoted that there is a standard deviation of approximately 14 Respondents about their opinion.

\section{FINDINGS}

\section{Findings Suggestions Conclusion Questionnaire Bibliography}

1. $92 \%$ of the Respondents were believed that S.B.I. Bank provides all Banking needs.

2. Majority of the Respondents were preferred savings account when compared with all the remaining mode of accounts, i.e, $67 \%$.

3. $42 \%$ of the Respondents were believed in S.B.I. Bank provides loan Facilities to the customers in an easy manner.

4. Recreation Facility given by the S.B.I. Bank was believed by $44 \%$ of the Respondents.

5. Only $38 \%$ the Respondents will aware of the list of shares in stock exchange provided by S.B.I.Bank.

$6.65 \%$ of the Respondents were believed that S.B.I.Bank gave Core banking facility to the customers.

7. Majority of the Respondents were felt that the S.B.I. Bank will not charge unnecessarily for not maintaining of minimum balance.

8. Majority 57\%of the Respondents felt that the S.B.I. Bank provides a competitive interest rate.

9. It is observed that $76 \%$ of the respondents felt difficulty while opening an account in the S.B.I. Bank.

$10.93 \%$ of the Respondents were recommended to their friends, relatives about the S.B.I. Bank.

11. Most of the Respondents were not preferred an alternate Bank instead of the S.B.I. Bank.

12. $72 \%$ of the Respondents were felt that the S.B.I. Bank will not take any service charge without any cause.

13. While asking the feedback about the S.B.I. Bank services $45 \%$ of the Respondents were felt very well on service.

14. It is observed that the $70 \%$ of the Respondents were preferred on personalized service of the S.B.I. Bank.

15. $58 \%$ of the Respondents were felt satisfied on solving of the banking problem by the S.B.I. Banking staff.

16. $59 \%$ of the Respondents were felt prompt service of the S.B.I. Bank.

17. Most of the Respondents were felt that the S.B.I. Bank would not restrict on maintaining of minimum balance is must in high.

18. It is observed that the $84 \%$ of the Respondents were satisfied on financial transactions of the S.B.I. Bank.

19. $64 \%$ of the Respondents were felt that the S.B.I. Bank would provide on savings account.

20. While asking the suggestions of the Respondents relating to the S.B.I. Bank, they felt that the Bank must Create an awareness regarding the Online transactions to the Customers. 


\section{SUGGESTIONS}

1. From the above findings it was found that one of the S.B.I.Bank provided services is Online transactions. That is not much known to the customers, therefore the Bank management should take efforts to make awareness among the general public about online facilities.

2. Since $73 \%$ of the customers using savings account deposits in every Bank. So the Bank management should think of introducing new schemes regarding savings accounts and marketing those to the customers.

3. While discussing with the customers about suggestions they want more information on loans with interest rates provided by the Bank. So the Bank should employ some contact persons through a toll free number.

4. Since $23 \%$ of the Respondents were dis-satisfy on transactions at Bank and time consumed too. To avoid this problem the Bank management should recruit more employees.

5. Majority of the customers will prefer online bill payment facility provide by S.B.I.Bank. so the management should give low service charges and offering prices on Online Bill Payments.

6. Advertisement of S.B.I.Bank is very less when compared with the competitors. It may leads to switching on other Banks. To overcome the Bank management should promote more advertisements through various advertisement vehicles.

7. Most of the customers felt that opening of an account is very difficult in the Bank. So the management should take care on new customers as well as old customers

8. Only $24 \%$ of the customers will aware of the availability of shares in stock exchange. So the management should display their types of securities like equity shares, bonds, debentures etc in their branches.

9. The discussions of the customers, mostly to expanding of the branch for their convinence. The management try to expand the branch for customers' convenience.

10. Since private sector Banks are the main competitors of the SB.I.Bank.So the Bank management should always work out special market strategies to retain the current customers and also bring out the market share of S.B.I.Bank customers, by regular advertisements, improving service quality, introducing new schemes for the customers.

\section{CONCLUSION}

Some light was shed on some negative factors also like creating an awareness on online transactions, interest rates on loans, A.T.M. facilities etc.,That's why Some suggestion were provided to the management like concentrating on Online services, solving banking problem with a quick time and promote loan facilities like industrial,business,agriculture, individual loans etc, with an attracting advertisements.

\section{Questionnaire}

I. A survey On Customer Satisfaction In Banking Services

1. Name:

2. Address :

3. Occupation :

4. Annual Income :

5. Name of your Bank:

II. 6. Do you think that your s.b.i. bank caters all your banking needs?
(a) Yes
(b) No
(c)cannot say

7. Which of the following facilities is given more importance in your s.b.i bank
(a)Loan facilities
(b) $\mathrm{O} / \mathrm{D}$ facilities
(c)ATM facilities

Does your bank conduct any recreation facilities for the customers
(a) Yes
(b) No
(c)cannot say

08. Does your bank have listed its share in stock exchange
(a) Yes
(b) No
(c)Not Aware

09. Does your bank have core banking facility for the customers
(a) Yes
(b) No
(c)Not Aware

10. Do they charge unnecessarily for not maintain minimum balance in your account
(a) Yes
(b) No
(c)Not Aware

11. Does your bank offers competitive service charges
(a) Yes
(b) No
(c)Not Aware

12. Do you think your bank offers competitive interest rate
(a) Yes
(b) No
(c)Not Aware

13. Do you use the service of alternative bank
(a) Yes
(b) $\mathrm{No}$
(c)Not Aware 
14. What do you feel about overall service quality of your bank.
(a)Excellent
(b)very good
(c)good (d)average
(e)poor

15. Would you recommend this bank to your friends, relatives, associates
(a) Yes
(b) No
(c)Not Aware

16. When do you think of your bank what comes first in your mind
(a)Personalized service
(b)Wide branch network (c)Customer

service $\quad$ (d)computerized banking (e)Core banking

17. Your over all opinion about this survey
(a) Satisfactory
(b)Will yield result
(c)looking forward for result

18. How satisfied are you with the services provided by the bank?
a) Very satisfied b) Satisfied
c) Somewhat satisfied
d) Dissatisfied

19. Do you always get prompt service whenever you visit the branch?
a) Always
b) Often c) Sometimes
d) Rarely
e) Never

20. Are you satisfied with your financial transactions with the bank?
a) Very satisfied b) Satisfied
c) Somewhat satisfied
d) Dissatisfied

21. What type of banking account is owned by you?
a) Savings account
b) Loan account c) Transaction deposit
d) Current account

e) Joint account

22. How long have you had these accounts in the bank?
a) Less than a year
b) 1-3 years
c) 3-8 years
d) More than 8 years

23. Are you satisfied with the current service offerings of the bank?

$\begin{array}{lll}\text { a) Yes b) No } & \text { (c)cannot say }\end{array}$

24. Are you able to use banking services online?

$\begin{array}{lll}\text { a) Yes b) No } & \text { (c) cannot say }\end{array}$

25. How many times have you faced a problem related to your banking account in the last 1 year?
a) Once
b) $1-5$ times
c) 5-10 times
d) More than 10 times

e) Never

26. How quickly were your banking problems and issues addressed by the bank staff?
a) Immediately b) Within 24 hours
c) Within 48 hours
d) Within 3-5 business days

e) More than a week

27:Since how long are you using the online banking system provided by our bank?

1.Below 1 month 2. $1-6$ months 3. 6 months -1 year

4.Above 1 year

28:What is the major purpose for which you use the online banking?

1.Online Ticket Booking 2.Online Bill Payments 3.Balance Check

4.Request for a cheque book 5.Others. Please specify

29:Are you satisfied with online banking?
1.Yes
2.No
(c)cannot say

30. What is your feedback regarding the bank's Customer Service Representatives?

a) Answer calls quickly b) Knowledge about banking products

c) Knowledge about banking services d) Banking issues handled quickly

g) Good communication skills

\section{References}

[1]. Personnel Management -- $\quad$ Mamoria, C.B.,Himalaya Publications, $21^{\text {st }}$ edition, 2001.

[2]. Personnel and Human Resource Management -P.Subba Rao, Himalaya Publications, 2008.

[3]. Marketing Management -Philip Kotler, $13^{\text {th }}$ Edition.

[4]. Research Methodology -C.R.Kothari,New Age Publishers, $2^{\text {nd }}$ Edition,

[5]. M. Kailash, A Study on Customer Satisfaction with Service Quality in Indian Public and Private Sector Banks: Golden Research Thoughts (March 2012)

[6]. Hummayoun Naeem, Asma Akram and M. Iqbal Saif, 'Service Quality and Its Impact on Customer Satisfaction: An Empirical Evidence from The Pakistani Banking Sector', International Business \& Economics Research Journal -December 2009 Volume 8, Number 12 pp. $99-104$

[7]. Uma Sankar Mishra, Bibhuti Bhusan Mishra, Saroj Kanta Biswal and Bidhu Bhusan Mishra, "Employee Evaluations of Customer Satisfaction: A Comparative Study between Public and Private Banks in India", International Research Journal of Finance and Economics ISSN 1450-2887 Issue 59 (2010), pp134-144

[8]. Ushad Subadar Agathee "An Assessment on Service Quality in the Mauritian Banking Sector" International Research Symposium in Service Management ISSN 1694-0938, (2010) pp 1-16

[9]. Kajal Chaudhary and Monika Sharma, "Performance of Indian Public Sector Banks and Private Sector Banks: A Comparative Study”, International Journal of Innovation, Management and Technology, Vol. 2, No. 3, June 2011 
[10]. Surabhi Singh and Renu Arora, “A Comparative Study of Banking Services and Customer Satisfaction in Public, Private and Foreign Banks", J Economics, (2011) 2(1): 45-56

[11]. Roth, Aleda V, van der Velde, Marjolijn, Operations as Marketing: A Competitive Service Strategy, Journal of Operations Management, 1991; 10(3): 303-328.

[12]. Abratt, R and Russell, J. (1999). Relationship Marketing in Private Banking South Africa. The International Journal of Bank Marketing, 17(1), p.5.

[13]. Dawkins, P. M and Reichheld, F. F. (1990). Customer Retention as a Competitive Weapon.Directors and Boards, 14(4).

[14]. Marple, M and Zimmerman, M. (1999). A Customer Retention Strategy. Mortgage Banking, 59(11), August, pp. 45-50.

[15]. Page, M., Pitt, L and Berthon, P. (1996). Analysing and Reducing Customer Defection. Long Range lanning, 29(6), pp. 821824.New Delhi.

\section{Websites Preferred:}

1. www.sbi.co.in.

2. www.google.co.in 